\title{
MONOMODAL AND MULTIMODAL INSTANTIATIONS OF CONCEPTUAL METAPHORS OF BREXIT ${ }^{1}$
}

\author{
Olena Morozova
}

\begin{abstract}
Morozova, O. (2017). Monomodal and multimodal instantiations of conceptual metaphors of Brexit. In Lege artis. Language yesterday, today, tomorrow. The journal of University of SS Cyril and Methodius in Trnava. Warsaw: De Gruyter Open, 2017, vol. II (2), December 2017, p. 250-283. DOI: 10.1515/lart-2017-0017 ISSN 2453-8035
\end{abstract}

\begin{abstract}
This article offers a linguistic analysis of the conceptual metaphors of Brexit, in which the source and the target belong to the same semiotic mode or to different ones. It is shown that the variation of high-level cognitive models underpinning metaphoric images of Brexit reflects the author's stance towards the event. Phases of Brexit are associated with different image-schematic cognitive models, and this impinges on the range of those metaphors of Brexit that involve low-level concepts.
\end{abstract}

Keywords: Brexit, cognitive model, conceptual metaphor, Internet, monomodality, multimodality.

\section{Introduction}

This study looks at monomodal and multimodal instantiations of the conceptual metaphors of Brexit in traditional and new media ecologies. Reflecting upon the dictionary meaning of the term 'Brexit' (the withdrawal of the United Kingdom (UK) from the European Union (EU) (OED, s.a.), a British journalist Matthew Tempest remarks that it is 'both narrow - and vague - enough to satisfy most people' (Tempest 2017). Obviously, by 'most people' he means the least critical and / or inquisitive part of the population, whom he believes to be in the majority. In spite of this disputable point, he is undoubtedly right in assuming that a dictionary definition is not capable of capturing all the cultural, political, and economic implications of the withdrawal of the

\footnotetext{
${ }^{1}$ This article is a part of the transnational research project "Crisis, conflict and critical diplomacy: EU perceptions in Ukraine and Israel/Palestine (c3EU)" supported by Jean Monnet Programme of the European Commission.
} 
UK from the EU. In order to make better sense of Brexit, it is necessary to consider the environment, in which the messages about it are generated and contested. A broad context of the UK and EU relationship is presented in 2.1.

In addition to its social significance, Brexit has turned out to be attractive to linguists. Thus, Musolff (2017) considers the dynamics of a metaphor that has dominated the UK-EU discourse for over two decades - BRITAIN AT THE HEART OF EUROPE, reaching its culmination point with Brexit.

Since my study focuses on the conceptual metaphors of Brexit, which I treat as dynamic discourse formations, and not stable cognitive representations stored in speakers' minds, I consider it necessary to clarify what kind of cognitive modelling fits this approach best. In 2.2, in the spirit of van Dijk (2008a), I argue that it is the situational model rather than the cultural model that is capable of capturing the contextually rich nature of the metaphoric images of Brexit.

Situation models have the capacity to construct meaning from what is conveyed by various semiotic means - both by verbal (written or spoken text) and non-verbal (visual images, music, gestures, posture, eye-gaze, facial expression, touch, smell, etc.). People interpret signs that belong to different semiotic systems simultaneously, or, in different terms, concurrently process information that comes via different channels, or modes (Forceville 2009: 23-14). This entails that conceptual metaphors of Brexit can be both monomodal (for instance, verbal or pictorial) and multimodal, i.e. represented in a combination of different modes, in particular, verbal and pictorial (Morozova 2017).

In present-day communication and media studies, it is universally accepted that the type of medium affects the way messages are constructed (McLuhan 1994). This postulate holds true for multimodal metaphors, among other linguistic phenomena. Metaphors may be 'purely multimodal' only in traditional formats of transmitting 
information - paper or broadcast. In the new media ecology - the Internet - hypermodal metaphors can also be found.

My sample has two important constraints: firstly, the array contains cognitive metaphors of Brexit that appeared in the mass media in the time span of a year and a half, from June 2016 to October 2017; secondly, multimodal and hypermodal metaphors of Brexit are considered only in static images (a picture, a photo, a cartoon) found on the Internet. An overview of the up-to-date research into monomodal, multimodal, and hypermodal conceptual metaphors is given in 2.3 .

The aims of the article are twofold, though to a certain extent overlapping. The first one is to reconstruct the situation model of Brexit by drawing on the data available in Internet texts about Brexit and Internet memes on Brexit with a view of establishing the place of the stance component of the meme's author in it. The second one is to consider the structure and functions of the monomodal (verbal, written) and multimodal (verbal-pictorial) conceptual metaphors of Brexit in order to bring to light their stance-constructive potential and politically relevant implications.

It is argued that English speakers endow Brexit with particular traits with the help of verbal and non-verbal (visual, for this research) means as well as their interplay. With the help of monomodal and multimodal conceptual metaphors, a broad spectrum of features is profiled, evaluated positively or negatively, and re-evaluated in order to express a particular stance of the speaker / writer.

I believe the research to be relevant for the development of present-day linguistics since it aims to go beyond Conceptual Metaphor Theory in its classic version (Lakoff \& Johnson 1980) to the areas of Multimodal Metaphor (Forceville 2009) and Hypermodal Metaphor as well as into Critical Discourse Studies.

Structurally, the article consists of four parts: (1) the introduction, (2) theoretical prerequisites and methodology, (3) results and discussion, and (4) the conclusion. The 
introductory part provides working definitions for the key terms ('Brexit', 'situation model', 'multimodality', 'hypermodality', and 'conceptual metaphor'), presents the aim and scope of the research, gives arguments for its relevance, and outlines the structure of the whole paper. Part 2 provides the theoretical background and methodology for the study of the monomodal and multimodal conceptual metaphors of Brexit. Part 3 presents the results of the research and offers a discussion. The conclusion sums up the results and outlines prospects for further research.

\section{Theoretical prerequisites}

\subsection{Brexit in its historical context}

The word Brexit appeared in 2012 to denote the withdrawal of the United Kingdom (UK) from the European Union (EU) and the political process associated with it (OED, s.a.). Structurally, Brexit is a portmanteau word coined by compounding two etymons - British and exit, in the style of the term Grexit (from Greek and exit), which appeared earlier in the same year to denote the threatened exit of Greece from the EU. This wordbuilding model has turned out to be quite productive in the times of uncertainty concerning the EU's future: it has brought to life such coinages as Frexit, Italexit, Swexit, Scoxit, etc. (Brexit wins! 2016).

This linguistic fact alone may serve as an indication of the social significance of Brexit, since only those things that are of importance for people are laid down in language. This linguistic evidence agrees with the estimation of Brexit by British political scientists who call the withdrawal of the UK from the EU "the most important and consequential piece of public policy since at least the Second World War" (Usherwood 2017). In 2016, alongside the presidential election in the USA, Brexit was given such broad, controversial, and emotionally charged media coverage that the frequency of the word post-truth spiked, and it was chosen as the Oxford Dictionaries' Word of the Year (Oxford Dictionaries, s.a.). Post-truth is defined as "relating to or denoting circumstances, in which objective facts are less influential in shaping public opinion than appeals to emotion and personal belief" (Oxford Dictionaries, s.a.). 
Considered in the context of the relationship of Britain with continental Europe, the UK leaving the EU is not at all surprising. Professor of International History Jussi M. Hanhimäki observes that this relationship has always been lukewarm: Britain engaged with Europeans either in imperial contest or as an 'external' force aiming to prevent one nation (from Napoleon's France to Hitler's Germany) from dominating continental Europe (Hanhimäki 2016). After 1945, the relationship did not become any warmer: the British positioned themselves as 'reluctant Europeans', accepting free trade arrangements but opposing other forms of integration (a single currency or the Schengen agreement) (ibid.).

For over half a century successive British governments structured the UK's political and economic engagement with Europe with a varying degree of enthusiasm. Euroscepticism gained significant traction in the UK in the Thatcher years (19751990), leading to the foundation of a cross-party coalition against the UK's involvement in European integration (later renamed as the UK Independence Party - UKIP). Further, the UK opted out of the European single-currency zone. The Eurosceptic position was somewhat weakened under Tony Blair's leadership (signing of the Lisbon Treaty that gave Brussels broader powers). The second decade of the $21^{\text {st }}$ century (the Cameron years 2010-2016) saw a resurgence of euroscepticism evident in the rise of eurosceptic parties communicating strong anti-EU messages to growing numbers of voters and in the UK's opting out of the European single-currency zone thus becoming 'a euro-outsider' (Adler-Nissen 2016).

The controversy between British eurosceptics and eurooptimists became eminent at the referendum on June 23, 2016 where $51.9 \%$ of the voters expressed their wish for the UK to leave the EU. The results were 'nail-bitingly close' (Hanhimäki 2016), and yet they made it possible for Prime Minister Theresa May to trigger Article 50 of the Treaty of Lisbon in March 2017, thus marking the start of a two-year process of Britain's exit from the EU, which is to be completed in spring 2019. 
Brexit has influenced both the UK and the EU in quite a number of aspects - economic (trade), financial (budget), political (army power), etc. The future outcomes and sideeffects for both parties are highly uncertain and will depend on long-term decisions, negotiations and developments (Sia partners 2016).

The political implications of Brexit lie in the sphere of soft and hard power. Coined by Nye (2005) in the late 1980s, the term 'soft power' denotes a strategy in foreign international relations, the ability of a country to persuade other countries to do what it wants without force or coercion. Alternatively, hard power is the strategic line of a country aimed at changing the behaviour of other countries by applying its military and / or economic might. The EU has contributed highly to the image of the UK as the strongest soft power worldwide (Sia partners 2016), and without the UK, the EU would lose a strong voice in the G8, the UN Security Council and beyond (G20, NATO, IMF, World Bank and the Commonwealth). Within global political conflicts (Iran, Iraq, Islamic State, or Syria), the UK, which is heavily investing in its military power, demonstrated its hard power. This explains why the EU's worldwide credibility strongly depends on the policies adopted by the post-Brexit UK in its foreign international relations.

The financial implications of Brexit are rooted in the fact that currently the UK attracts more foreign investment than any EU member state and is home to a great number of corporate headquarters. Analysts predict that this state of things is bound to change in favour of individual EU member states if they manage to create an appropriate investment and business-friendly environment (Sia partners 2016). In addition, as the UK is a major contributor to the budget of the EU, the monetary obligations of the UK are to be taken on by other EU member states, which will be a major challenge. Brexit 
will also affect the UK's trade relations with the EU countries. Before Brexit, up to $40 \%$ of euro trading was done in the City of London, and now the activities would have to move to other places, probably to Frankfurt or Paris (ibid.).

Evaluating the post-Brexit stances of the UK and the EU, analysts predict that the UK will try to find a good balance between sustaining the belief in the EU and giving a clear message that 'out of the EU' is not the same as 'in the EU', while the EU will try to work out a deal, which is less beneficial to the UK than EU-membership but still advantageous to both sides (ibid.).

Overall, Brexit has turned out to be 'a rare game changer' in European and international affairs (Hanhimäki 2016), adding a new problem to the EU, alongside those of migration flows and the atrophy of the Eurozone economy (Whitman 2016: 509). From the UK perspective, the country has not confronted a more uncertain environment within which to pursue a European strategy since the end of the Second World War (ibid.).

\subsection{Modelling Brexit: a cultural or a situational model?}

Present-day scholars hold the assumption that the process of discourse production, understanding, and recall is affected not by real-world situations per se, but by their abstractions formed in speakers' minds. Consequently, there is a mental mechanism, which filters through infinite lists of features of real-life events and situations in order to sort out those relevant for ongoing communication. The products of its work are called 'mental models' (Johnson-Laird 1983), which are representations of an event or situation in the discourse participants' minds. Today, these mental representations are more often referred to as cognitive models (Ruiz de Mendoza \& Galera Masegosa 2014: 75).

Currently, the issue of the nature and functions of cognitive models remains very much on the research agenda of linguists of various persuasions. Cognitive linguists, for 
instance, apply such varieties of cognitive models as propositional models, idealized cognitive models, image schemas, frames, domains, their combinations, and extensions. An up-to-date detailed discussion of the issue is given by Ruiz de Mendoza and Galera Masegosa (2014).

The cognitive models listed above relate to static mental representations stored in the long-term memory and shared by all speakers of a language. Ruiz de Mendoza and Galera Masegosa (op. cit.) draw a distinction between primary, low-level, and highlevel cognitive models. They maintain that primary cognitive models relate to those concepts that are directly grounded in our sensory experience, as the one verbalized by the contrasting pair up / down (op. cit.: 64). Low-level cognitive models are framelike configurations of elements that belong to our encyclopedic knowledge, like scenarios (e.g., going to a dentist) and object-related concepts (e.g., table, robin) (ibid.). High-level cognitive models, like action, object, etc., emerge in the process of abstracting features shared by a number of low-level cognitive models (ibid.).

However, as van Dijk rightfully claims, in discourse production speakers or writers will generally start not from a shared cognitive model of an event or situation, but from their personal ones that organize their subjective beliefs about the situation (van Dijk 2008a:162). Therefore, a distinction between 'cultural cognitive models' and 'situation cognitive models' seems not only lawful but also expedient.

Cultural models are static: they are stored in the long-term memory, organizing shared knowledge of things, events or situations of a certain type. In East-European linguistics, they are known as concepts. Cultural models, or concepts, are rather broad conceptual entities (for recent research into the problem see Davydyuk \& Panasenko 2016; Uberman 2016). Consequently, those engaged in conceptual studies treat concepts as entities that embrace cognitive models of all ranks (primary-, low-, and high-level). 
In contrast to cultural models, situation models are dynamic. They are constructed online in discourse participants' minds, capturing relevant properties of the situation under consideration and organizing them in a systematic way (van Dijk 2008a:163). The knowledge structured by a situation model is unique, defined in terms of subjective participant constructs. Situation models are instantiations of cultural models, thus they represent only a certain portion of respective cultural models, but they usually characterize it in more detail, evoking richer associations. Situation models are not 'prefabricated' mental entities stored in memory and ready to be extracted: they are constructed only as a need for them arises. In that, the notion of a situation model is close to the notion of a mental space originally described by Fauconnier as a small conceptual packet constructed as we think and talk, for purposes of local understanding and action (Fauconnier \& Turner 2002: 40).

Kövecses' view of the problem of cognitive modelling (Kövecses 2017) entails that such conceptual structures as image schemas, domains, frames, and mental spaces can be arranged into a continuous hierarchy. Following Johnson (1987) and Lakoff (1987), he treats image schemas as directly meaningful preconceptual structures, analogue patterns that have an internal structure that consists of only a few parts, for example, MOTION, CONTAINER, etc. (Kövecses 2017: 211). He defines a domain after Langacker (1987: 488) as a coherent area of conceptualization relative to which semantic units may be characterized. Domains like JOURNEY, BODY, and BUILDING illustrate the case. Unlike image schemas, domains are propositional structures, not analogue; they are quite abstract, though more information-rich than image schemas. Due to that, Kövecses (2017: 211) places domains immediately below image schemas in his hierarchy of conceptual models. After Fillmore (1982: 111), Kövecses understands the notion of a frame as any system of concepts related in such a way that in order to understand any one of them one has to understand the whole structure into which it fits. It is obvious that such a definition of a frame is close to Langacker's definition of a domain. Kövecses (2017: 212) holds that frames involve more conceptually specific information than domains, and thus frames and domains 
differ in the degree of schematicity. In their turn, frames consist of slots (or roles, in Kövecses' terminology) and relations between them. In actual communicative situations, these slots are filled with particular information content that interacts with contextual information, thus resulting in the formation of mental spaces.

The above-considered cognitive models correlate in the way that is schematically presented in Table 1 below.

Table 1. Correlation of the notions of a cultural model, concept, situation model, mental space, image schema, frame, and domain as treated by different scholars

\begin{tabular}{|l|l|l|l|l|}
\hline $\begin{array}{l}\text { van Dijk } \\
(2008)\end{array}$ & $\begin{array}{c}\text { Fauconnier } \\
\text { \& Turner } \\
(2002)\end{array}$ & $\begin{array}{c}\text { Conceptual studies } \\
\text { in East-European } \\
\text { linguistics }\end{array}$ & $\begin{array}{c}\text { Ruiz de Mendoza } \\
\text { \& Galera } \\
\text { Masegosa (2011) }\end{array}$ & $\begin{array}{c}\text { Kövecses } \\
(2017)\end{array}$ \\
\hline $\begin{array}{l}\text { cultural } \\
\text { model }\end{array}$ & & concept & $\begin{array}{l}\text { primary cognitive } \\
\text { model }\end{array}$ & image schema \\
\cline { 4 - 5 } & & $\begin{array}{l}\text { high-level } \\
\text { cognitive model }\end{array}$ & domain \\
\cline { 4 - 6 } & & $\begin{array}{l}\text { low-level } \\
\text { cognitive model }\end{array}$ & frame \\
\hline $\begin{array}{l}\text { situation } \\
\text { model }\end{array}$ & $\begin{array}{l}\text { mental } \\
\text { space }\end{array}$ & & mental space & mental space \\
\hline
\end{tabular}

In this connection, I would like to make two remarks. Firstly, image schemas / primary cognitive models can hardly be said to fit into the hierarchy since they are, by definition (Johnson 1987: 19-21; Lakoff 1987: 459-461), highly schematic preconceptual structures grounded in perceptual interactions of humans with the world around them. Being preconceptual, image schemas exist beneath human consciousness, prior to the formation of concepts, and consequently, can hardly be said to enter the same hierarchy with them. For the second point, I side with Zhabotynska (2010: 81) in her claim that frames are most abstract propositional schemas to be filled in with conceptual content, and not the content itself. Thus, frames are not 'ontologically parallel' to domains and concepts. It implies that in Kövecses' hierarchy it would have been more logical to use 
some other term to denote conceptual entities that correspond to low-level cognitive models (for example, 'concept'), and not the term 'frame' that represents the way such conceptual entities are organized. Yet, unlike the first consideration, this issue is of a terminological nature, and thus it does not influence the basic principles of the hierarchy considered above.

In the analysis to follow, I will proceed from the following hierarchy of cognitive models (Table 2):

Table 2. The system of conceptual structures adopted in this study

\begin{tabular}{|l|c|l|c|}
\hline Preconceptual & \multicolumn{3}{|c|}{ Conceptual (propositional) structures } \\
(analogic) structures & \multicolumn{2}{|c|}{} \\
\hline primary cognitive & high-level cognitive models & domains & cultural models \\
models = image & low-level cognitive models & concepts & (static) \\
\cline { 2 - 4 } schemas & mental spaces & situation models \\
& & (dynamic) \\
\hline
\end{tabular}

\subsection{Conceptual metaphor studies}

"Since Britain voted to leave the European Union, politicians and commentators have deployed everything from cakes, cherries, cats, even golf clubs to try to explain what it might all mean" (Landale 2017). This citation is just one amongst many of the same kind because for over a year now journalists and bloggers (Connolly 2017; Thrower 2017; Usherwood 2017, etc.) have been commenting upon the abundance of metaphors in the speech of those discussing Brexit - politicians, economists, scholars, and ordinary people. The diverse set of metaphors of Brexit is necessary in order to do justice to the complexity of this political phenomenon. In politics, as Brugman (2017) justly remarks, metaphors work by connecting political concepts to non-political concepts, and here I can add only that to a cognitive linguist it hardly comes as a surprise. 
Cognitive linguists adopt it as a postulate that metaphors are helpful when discussing things, which are new and / or complicated since they allow speakers / writers to bring to light certain aspects of such entities by likening them to more common / less complicated ones (Lakoff \& Johnson 1980). Undoubtedly, Brexit is a new phenomenon for European politics. An indication of its conceptual complexity is the fact that even prominent political figures are hard put to explain its essence. For example, the UK Prime Minister, Theresa May, unwilling (or just unable at the time) to share her vision for the process of the UK's withdrawal from the EU, offered her own ultimately laconic definition, which immediately became a sound bite: 'Brexit means Brexit'. So, even though public voices yearning 'for metaphors to stop' (Landale 2017) continue to grow, the time is ripe for linguists to describe metaphoric extensions of the concept BREXIT. In order to do this, it is necessary to stipulate the theoretical perspective, from which this issue is tackled here.

The present study draws on the Conceptual Metaphor Theory (CMT), the foundations of which were laid in the pioneering work of Lakoff and Johnson (1980) and developed in the scholarship to follow (Gibbs 2011; Grady 1999; Johnson 1987; Kövecses 2002; 2017; Lakoff 1987; Lakoff \& Johnson 1999; Lakoff \& Turner 1989, etc.). Researchers take as the basic CMT premise that the essence of conceptual metaphor lies in understanding one domain of experience (the target) in terms of another experiential domain (the source). Thus, conceptual metaphor is both the process and its end result. Conceptual structures of the source domain are mapped onto conceptual structures of the target domain, bringing with them a range of entailed attributes.

Although Lakoff and Johnson (1980) admit that the occurrence of metaphor is not confined to language alone, most researchers have considered mainly verbal metaphors. Nonetheless, if metaphors are 'primarily a matter of thought and action' (op. cit.: 5), then it is reasonable to assume that they are manifest not only in language but also in other semiotic systems (modes). However, for over two decades, little 
attention was paid to non-verbal metaphor. Only in recent years has research within the CMT been extended to other modes.

Within multimodal conceptual metaphor studies, three lines of inquiry can be identified. The first focuses on gesture (McNeill 1992; 2005; Metaphor and gesture 2008; Mittelberg \& Waugh 2009). The second concentrates on music (Zbikowski 2009). The third line of research directs attention to visuals of different kinds. The phenomenon of visual metaphor explored by Carroll (1994) and Forceville (1994; 1996; 2009) suggests that conceptual metaphors occur not only in various modes of representation, the visual mode in particular, but also in various combinations, for instance, verbal and visual. The present contribution lies within the scope of the third research line, focusing on verbal (the written mode) / visual (static images) multimodal conceptual metaphors.

\subsection{Data and methodology}

My sample consists of 200 verbal and multimodal metaphors extracted from traditional and new media sources during the period of June 2016-October 2017. This time span is provisionally divided into two phases according to the development of 'the Brexit scenario': (1) the Referendum phase (23 June 2016 - 29 March 2017) and (2) the phase of invoking Article 50 of the Treaty of Lisbon, which specifies the procedure for a country to leave the EU (29 March 2017 - ongoing). Technically, this phase is not over until 29 March 2019, yet the date when Brexit talks officially started (19 June 2017) can serve as a certain milestone in the two-year time limit provided for the negotiations. The verbal metaphors of Brexit (a total of 70) have been extracted from written texts (newspaper articles in English), while the multimodal and hypermodal examples (130)

- from Internet memes.

Internet memes are defined as units of information (ideas, concepts or beliefs) that replicate by passing on via Internet in the shape of hyper-links, videos, images, or phrases (Castaño 2013: 87). As Shifman (2013) suggests, Internet memes represent a 
new form of digital interaction in Web 2.0, are part of '(post)modern folklore' (op. cit.: 15), of an active culture shared on-line. Due to that, Internet memes can be thought of as a new form of civic participation (Lecheler 2014). Hence, Internet memes about Brexit are capable of providing a perspective on this event that may be interesting for political scientists and media studies experts. Yet it should be noted that Internet memes might be humorously charged without any serious political implications.

The Internet memes subject to analysis comprise those that include some text (Fig. 1) or are connected to it by a hyper-link (Fig. 2).

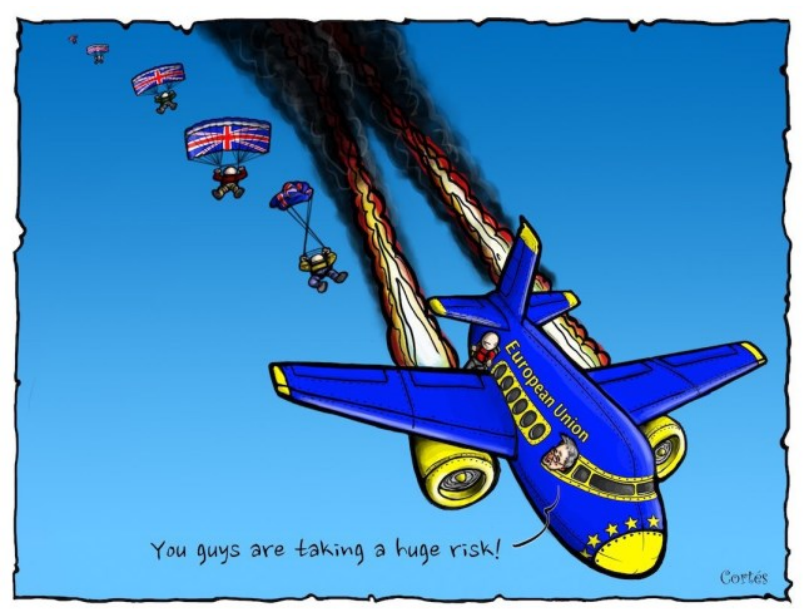

Figure 1. An Internet meme "Mayday!" comprising some text ('You guys are taking a huge risk!') (Durden 2016)

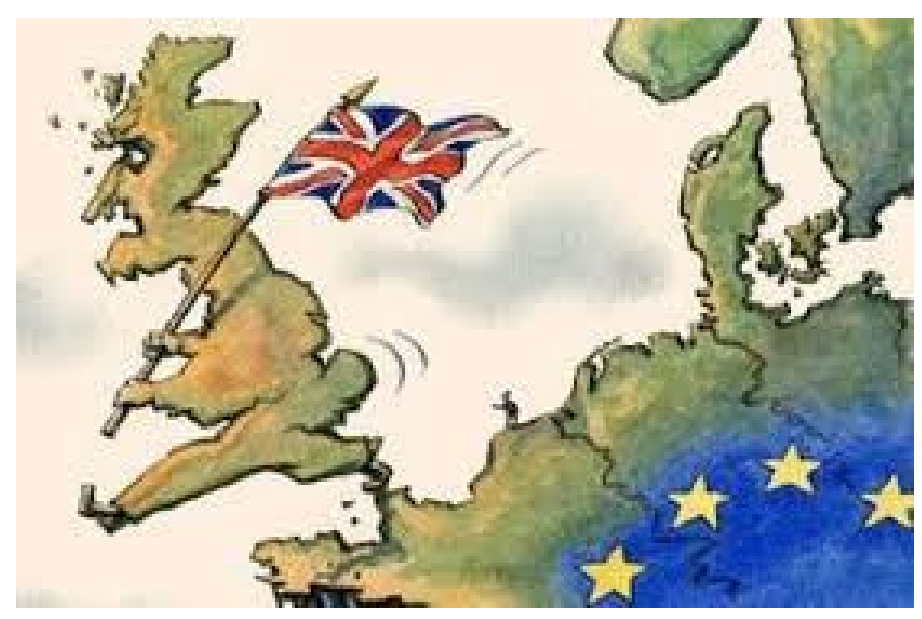

Figure 2. An Internet meme showing the image of the UK walking away from the EU (The funniest EU memes 2016) 
One can search Google by image by clicking on it. When one does this with the meme in Figure 1, the search takes him / her to the text "United Kingdom withdrawal from the European Union / Brexit - Mayday!", in the second case - to the text "On June 23 th, 2016, Britain voted on whether to leave the EU. And on June $24^{\text {th }}$, the voting results announced that Britain had decided to leave the EU". From the point of view of semiotics, both of the Internet memes are hypermodal (Lemke 2002) discourse formations, since in both cases by following hypertextual links the addressee can establish the connection of the images not only with origin entries, but with verbal tags as well. In Figure 1 these tags are $e u$, plane crash, parachute, union jack, great britain; in Figure 2 - britain and europe. Due to this, it seems more accurate to speak about multimodal conceptual metaphors that can be seen in Internet images superimposed with text (image macros) or images with captions (like in Fig. 1), and hypermodal metaphors in Internet images without any text included; yet they are connected to some text by hypertextual links. In my analysis, I have not drawn a distinction between multimodal and hypermodal metaphors, yet I believe it to be a promising direction for further research.

I proceed from the assumption that the concept BREXIT can be profiled against different domains, which gives rise to different ways of construing the mental space of Brexit, or its situation model. The latter can incorporate the 'inside' perspective (a UK citizen / organization, who / which supports the 'leave' or 'remain' campaign, is in favour of 'soft' or 'hard' Brexit, etc.) or the 'outside' perspective (the EU / EU member state / citizen of a member state). All these construals are mostly metaphoric, as has been pointed out in 2.3. Let us illustrate how metaphors of Brexit work.

The dictionary definition of Brexit given in 2.1 may serve as a basis for reconstructing a skeletal frame of the event (or its low-level cognitive model / concept structured as a frame): the withdrawal of the United Kingdom (UK) from the European Union (EU) and the political process associated with it (OED, s.a.): [ACTOR ${ }_{1}$ (The United 
Kingdom) - ACTS (leaves / withdraws from) - upon $\mathrm{ACTOR}_{2}$ (The European Union) - in a certain ENVIRONMENT (political process)].

In Lakoff and Johnson's terminology, BREXIT is an event-structure concept (Lakoff \& Johnson 1990: 170 et ff.). It can be profiled against such conceptual domains, as POPLITICS, ECONOMY, TRADE, CULTURE, SECURITY, IMMIGRATION, etc., which together constitute the domain matrix (Langacker 1987: 147) of this concept. This means that in different contexts, the semantics of the word Brexit can be made up of elements belonging to different conceptual domains, and the word itself, consequently, will carry positive or negative connotations depending on the type of the construal.

As all event-structure concepts, BREXIT can be rendered metaphorically in terms of more 'specialized' notions (Lakoff \& Johnson 1999: 171). Thus, ACTOR 1 (the United Kingdom) may be conceptualized as a HUMAN (examples 1,3) or as an OBJECT (example 2), his ACTION / its STATE (leaves / withdraws from) - as SELFPROPELLED MOTION (example 3) or as CHANGE OF STATE (example 4), $\mathrm{ACTOR}_{2}$ (the European Union) - either as another HUMAN (example 1) or as a CONTAINER (example 5).

(1) $<\ldots>$ what I do know for certain is that the EU wants the UK to settle any outstanding bills before it leaves $<\ldots>$. (Hunt \& Wheeler 2017)

(2) Sir Keir Starmer announced that the party now wanted to keep the UK in the single market $<\ldots>$ (ibid.); <..> part of the goal of Brexit was to remove the UK from the ECJ's jurisdiction. (ibid.)

(3) The UK has voted to leave the European Union. (ibid.)

(4) Most of the EU-derived laws on the UK's statute books will be copied across into $U K$ law so that businesses can continue to function on the day Britain leaves the EU, in March 2019. (ibid.)

(5) Who wanted the UK to stay in the EU? (ibid.) 
These concepts (HUMAN, MOTION, STATE, and CONTAINER) are 'fundamentally human concepts' that 'arise from human biology' (ibid.), and thus they belong to primary cognitive models.

This skeletal conceptual event-structure can be fleshed out inferentially, by primary metaphors (Grady 1999) inherent in it; for example, STATE can be conceptualized as BOUNDED REGION IN SPACE / CONTAINER, CHANGE - as MOVEMENT IN SPACE (Lakoff \& Johnson 1999: 176), etc. These metaphors use an image-schema as a source, yet metaphors of other types can also be used to enrich this basic structure, thus forming low-level cognitive models.

In my analysis, drawing a distinction between monomodal (verbal / written mode) and multimodal (verbal / written - pictorial / static) metaphors, I focus, firstly, on the status of the conceptual models (primary, high or low) involved in the process of metaphoric meaning construal, and secondly, on the 'life cycle' of a metaphor, namely, its belonging to a particular phase of the Brexit scenario.

\section{Results and discussion}

\subsection{Verbal metaphors of Brexit}

As has been previously shown, the meaning of the term 'Brexit' is based on a metaphor, where the UK ('Britain') is likened to a person, who has taken a decision to leave the place where he / she used to belong (the EU). This personification scheme has been elaborated in various verbal metaphors of Brexit that abound in newspapers and Internet blogs covering the development of the Brexit scenario that started with the Referendum on June 23, 2016. Among them 'adversarial' metaphors prevail, which construe Brexit as a competitive / antagonistic situation, such as sport, war, divorce, etc.

The concept SPORT serves as a source domain to numerous conceptual metaphors of Brexit that elaborate various aspects of the process. For example, at the end of 2016, 
there was still no negotiating strategy offered by the UK Government. In response to citizens' pleas to provide such information, Tom Fletcher, the UK's former Ambassador to the Lebanon, said that Muhammad Ali did not publish his strategy before the Rumble in the Jungle (Connolly 2017), thus applying the metaphor BREXIT is a BOXING MATCH. The analogy between Brexit negotiations and the historic boxing event in 1974 is easy to see. In the boxing match, Muhammad Ali after applied the strategy of 'rope-a-dope' exhaustion and defeated the world heavyweight champion George Foreman by a knockout at the end of the eighth round. The comparison of Brexit to a boxing match implies that the UK is going to be the winner. Though the UK's strategy of secretiveness is lawful, such behaviour cannot be called good sportsmanship, but rather a ruse. Yet, as Connolly (op. cit.) observes, the analogy between Brexit and boxing is 'dreadfully old-fashioned' since it ignores the obvious fact that the EU nations are vital trading partners, not participants in a zero-sum game.

The idea of contestation as opposed to cooperation is also present in comparing Brexit to a GAME OF CARDS. Newspapers report that Theresa May tends to 'keep her cards close' (Usherwood 2017), which implies that the EU is an opponent to the UK, an enemy to be defeated, from whom information should be withheld.

In essence, SPORT metaphors are very much like WAR metaphors, though without the coercive force element (op. cit.). Mass media started comparing Brexit to war during the first phase of Brexit, but the WAR metaphor became pervasive during the second phase, which started with triggering Article 50. Let us consider some headlines from "The Guardian". "The Brexit war can still be won, but I must start fighting back" (The Guardian, 2 November 2017); "The Dunkirk spirit: how cinema is shaping Britain's identity in the Brexit era" (The Guardian, 20 July 2017); "Brexit war of words heats up as 'enemy' EU tells Britain to pay up" (The Guardian, 13 October 2017). There is an opinion that war appeals to the British since it is 'part of their national psyche' (Usherwood 2017): they have won wars, stood strong in times of adversity, and the white cliffs of Dover have always been part of their defence against Europe. Yet this 
is a 'lazy argument' (ibid.) based on harmful endostereotypes. In the context of the UK negotiations with the EU, this metaphor is inappropriate since it fits in with the agonistic ideology that 'you get what you want by brutal strength'.

Another adversarial metaphor of Brexit uses DIVORCE as the source concept. The Google search for the collocations Brexit / UK / EU divorce bill yields a few hundred thousand hits (see, for example, Boffey 2017); also, there is a Wikipedia article "EU divorce bill" with over a dozen scholarly references (EU divorce bill, s.a.). Yet in spite of its seeming neutrality, at least when compared with war or boxing, the metaphor BREXIT is a DIVORCE is misleading in its very essence, and here metaphoric entailments are at work. It is common knowledge that divorce usually involves couples with an emotional relationship that is undergoing a crash. As a rule, after an acrimonious divorce, former spouses are loath to have to do anything with each other. However, in the context of the UK-EU relationship, such a scenario is not going to be beneficial to either party. Besides, one should not forget that one of the parties is made up of 27 different nations, so it is better not to stretch the comparison of Brexit to marital separation to unsustainable lengths.

Possible scenarios of the UK's withdrawal from the EU are a much-discussed topic today. It is talked over in terms of metaphors that use OBJECT as the source. The OBJECT is characterized with the help of a broad variety of contrasting attributes: soft vs hard / rough, clean / speedy / fast vs dirty / messy / phony, hairy vs shaven, spicy vs mild, and also 'white, red, and blue', as Theresa May believes would be better for the country (Brugman 2017). Thus, the BBC economics editor aptly remarks (with a pinch of salt) "Like eggs and cheese, Britain's departure from the European Union supposedly comes in both hard and soft versions" (Ahmed 2017). Metaphoric expressions hard Brexit and soft Brexit measure the extent to which the UK and the EU are ready to compromise on issues of their cooperation in the future. Hard Brexit implies intransigence of both parties, their unwillingness to meet each other halfway and therefore, a total divorce of the UK from the EU. In contrast to that, the collocation soft 
Brexit implies that the parties will maintain as close a relationship as possible (Brugman 2017).

Summing up my observations on the verbal metaphors of Brexit, I should point out that in their majority they are structural ones. They tend to involve complex reasoning, and several correspondences are simultaneously at work in the process of their discourse extension. This accounts for the considerable manipulative potential of such metaphors since different speakers can highlight different mappings entailed by them.

\subsection{Multimodal metaphors of Brexit}

Some of the verbal metaphors mentioned above have found their visual parallels, for instance, Sir Amyas Morse, the current comptroller of the UK's public spending, has compared Brexit to 'a chocolate orange' that might fall apart at the first tap (Landale 2017). Images of the chocolate orange followed suit on the Internet. This metaphor is hypermodal because for a person who sees the image depicting the source, but lacks the relevant contextual knowledge it might be quite challenging to reconstruct the target concept without following the hyperlink by clicking on the image.

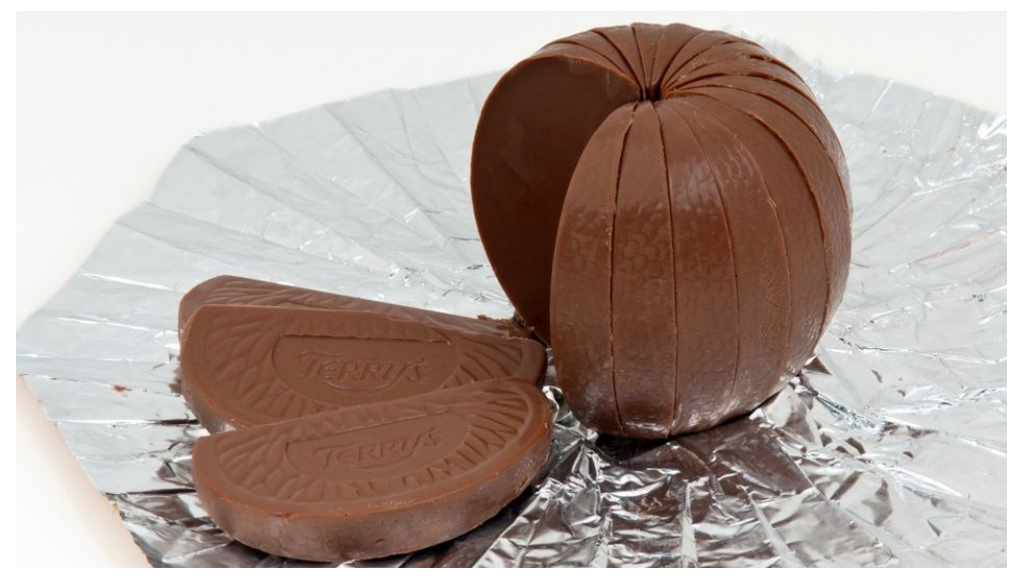

Figure 3. The visual image of the source concept of the metaphor BREXIT is A CHOCOLATE ORANGE (Landale 2017)

It might be not so easy, however, to visualize Charlie Elphicke's (Tory MP) comparison of the EU to 'Hotel California', where 'you can check in any time you like, but you can 
never leave'. In a similar way, the comparison of Brexit to a strawberry pudding, which was given by a culinary blogger Miriam Gonzalez Durantez (international lawyer and wife of Nick Clegg), would be hard to depict due to the unusual elaboration of this metaphor: "The crumble, just like Brexit, seems fine on the outside, though if you look attentively, you can see that there is a mess bubbling up inside. And it will definitely fall apart when you serve it, no matter how hard you try" (Landale 2017). These considerations account for the fact that multimodal metaphors of Brexit in their 'pure' variety are not as abundant as verbal metaphors. At this junction, I should mention that multimodal metonymic instantiations of Brexit are plentiful. Here belong, for example, images of flags (the Union Jack, the Flag of Europe), maps of Europe and the UK, pictures of the queen, etc. I am going to consider such images only if metonymy combines with metaphor, thus forming multimodal metaphtonymy. Let us consider some examples of the kind.

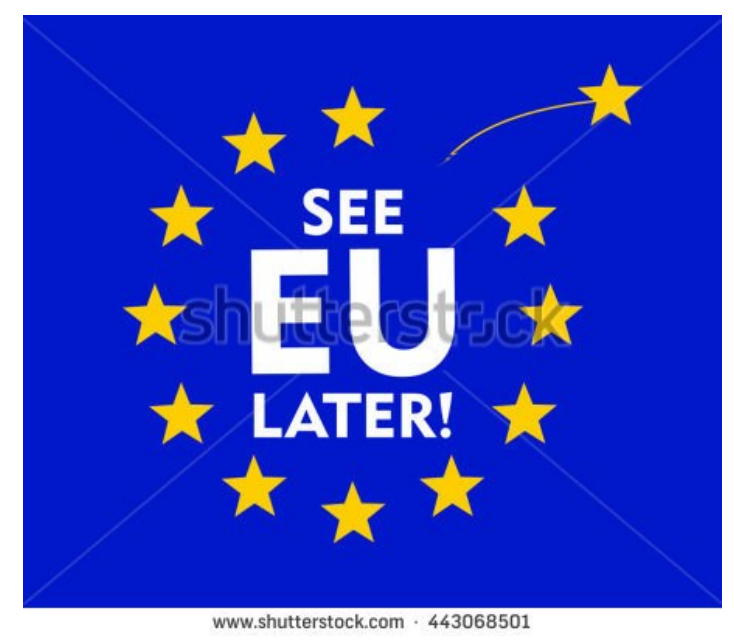

Figure 4. Metaphtonymic depiction of Brexit as a star (the UK) flying off the Flag of Europe (Shutterstock 2016)

Here the two parties involved in Brexit - the UK and the EU - are depicted metonymically, as the Flag of Europe symbolizing the EU and a star flying away (a member state - the UK - leaving the EU). Also, the UK is personified since the star that is leaving the circle of other stars says in a cheerful (or maybe casual) manner "See EU [si:ju:] later!". At any rate, no bad feeling is implied. 
The multimodal metaphtonymy of Brexit in Figure 5 is also based on 'ideological symbols' (Zheltukhina et. al. 2017: 12007) and personification, yet it lacks the easygoing manner of the previous image: there is an empty spot in the circle of remaining stars, which is no longer complete. Thus, two seemingly very similar multimodal metaphtonimies demonstrate varying stances on the issue of Brexit.

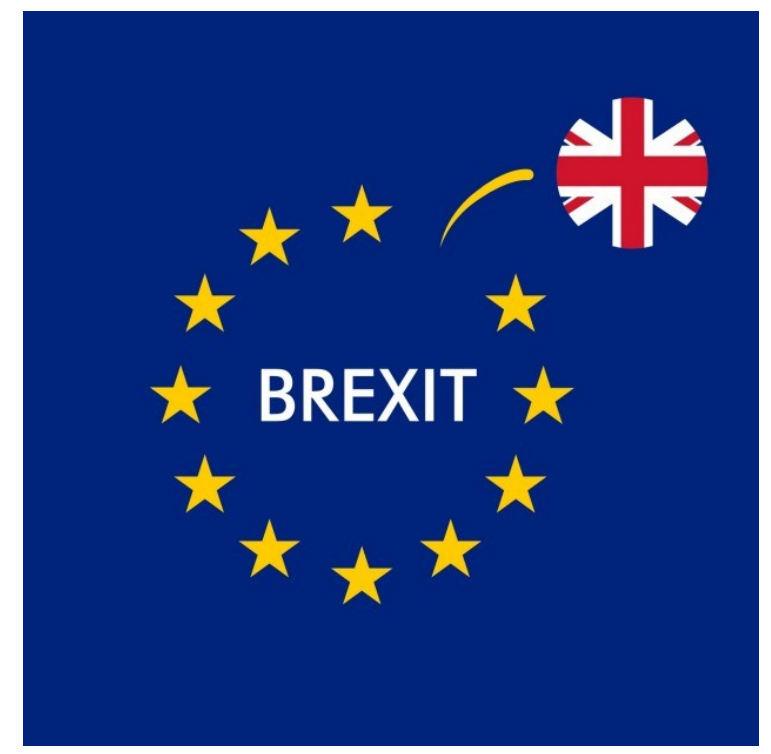

Figure 5. Metaphtonymic depiction of Brexit as a star (the UK) flying off the Flag of Europe (UK flag separating from European Union flag 2017)

The UK's withdrawal from the EU can provoke even relief, as in Figures 6 and 7. In Figure 6, the UK and the EU flags form the background (rather dark, barely distinguishable) for the words Well, I guess EU has now $1 G B$ of free space. This sentence contains a play on words: GB is an abbreviation for 'Great Britain' and 'gigabyte'. Thus, its meaning is alternatively profiled against the domains COMPUTER and ORGANIZATION. In the first case, we see the metaphors THE EU is COMPUTER MEMORY and the UK is INFORMATION. 


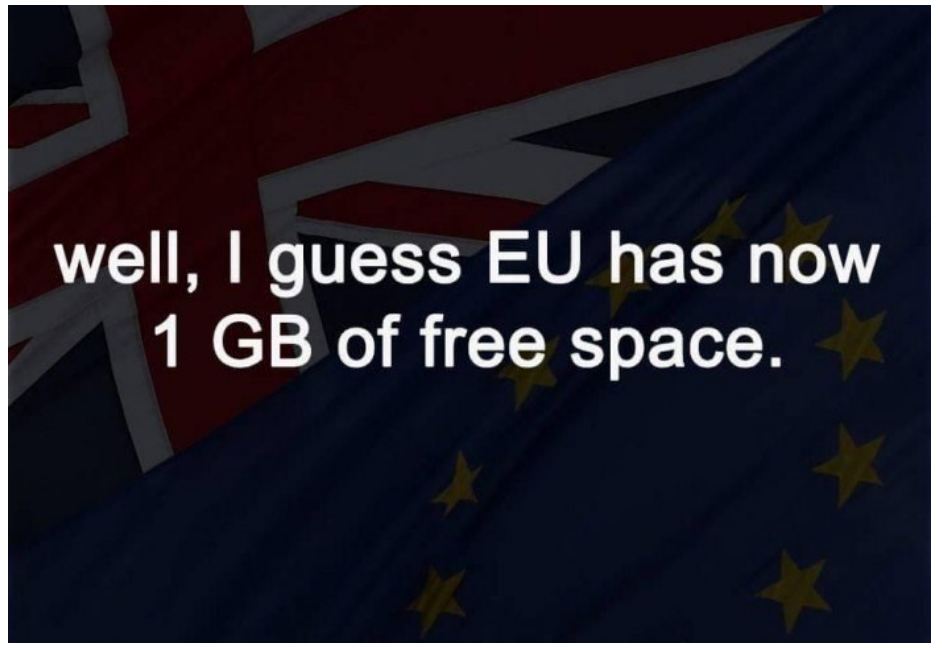

Figure 6. Reframing of the abbreviation GB-1 (Devhumour 2016)

This pun has gone viral, and in one of its variations, the source concept COMPUTER MEMORY is depicted metonymically as the pie diagram used in Word for Windows to show the state of computer memory.

The EU now has 1 ' $G B$ ' of free space.

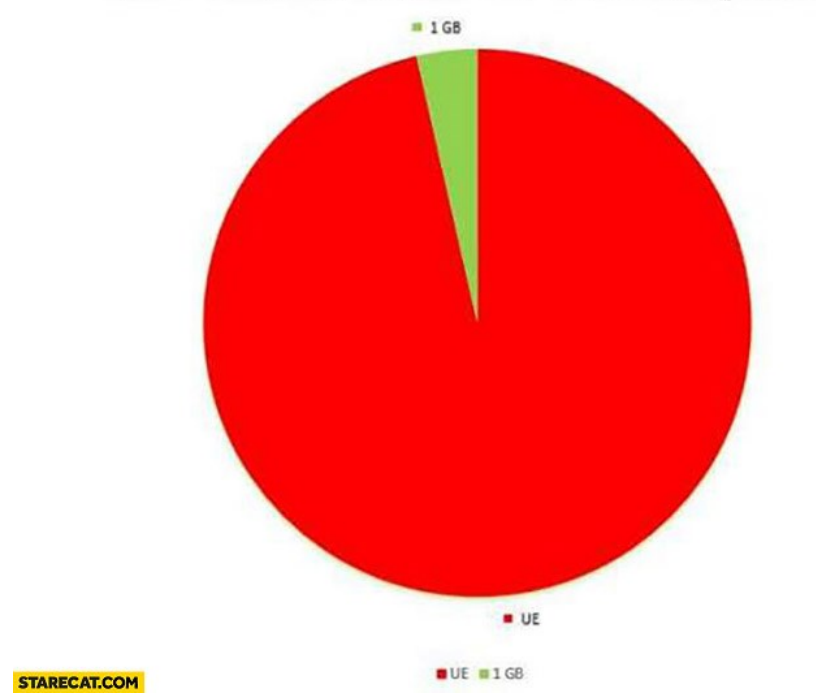

Figure 7. Reframing of the abbreviation GB-2 (Starecat.com 2016)

Overall, multimodal metaphors / metaphtonymies are more emotionally coloured than verbal metaphors. They appeal mostly to the emotional sphere, while verbal metaphors predominantly appeal to reason. Nevertheless, both monomodal and multimodal 
metaphors of Brexit clearly express the stance of their creator and have considerable persuasive potential.

\section{Conclusion}

The results of this study show that metaphoric representations of the United Kingdom's withdrawal from the European Union may be underpinned by different high-level cognitive models. Their variation reflects the author's stance towards the event: proponents of Brexit tend to conceptualize it as an ACTION of an ACTOR (the UK) who causes a dynamic controlled state of affairs to hold, while its opponents tend to present it as an uncontrolled PROCESS or a CHANGE OF STATE.

The phases of Brexit are associated with different image-schematic cognitive models: during the first phase (the Referendum / post-Referendum) adversarial metaphors prevail, while during the second phase (Article 50 negotiations) - elaborations of the OBJECT metaphor do. This impinges on the range of the image-based metaphors of Brexit that involve low-level cognitive models.

The monomodal verbal metaphors of Brexit (the written mode) tend to be used strategically in order to impose a particular ideological position upon the addressee by appealing to his rational sphere. Multimodal metaphors / metaphtonymies appeal mostly to the emotional sphere. Monomodal verbal metaphors tend to show a greater capacity for extension, thus helping the author to achieve his / her political ends, while multimodal visual-verbal metaphors have a propensity to elicit more intense and diverse emotions from the addressee, serving more to entertain than to persuade to take a particular political position.

Combining the affordances of multimodality and hypermodality, the creator of a metaphor enters into a dialogue with Internet users, thus resisting the monologism of traditional media genres, providing the addressee with an access to discourse diversity, and multiplying the potential of conceptual metaphors deployed in different modes. 
Research into monomodal and multimodal metaphors in their contrast and complementarity opens vast projects for exploring different spheres of human life, in particular, the political one.

\section{List of abbreviations}

CMT - Conceptual Metaphor Theory

EU - European Union

G8 - Group of Eight

G20 - Group of Twenty

IMF - International Monetary Fund

NATO - North Atlantic Treaty Organization

OED - Oxford English dictionary

UN - United Nations

UK - United Kingdom

UKIP - United Kingdom Independence Party

\section{References}

Adler-Nissen, R. (2016). The vocal euro-outsider: the UK in a two-speed Europe. In Political quarterly, 87 (2), p. 238-246.

Ahmed, K. (2016). What does 'hard' or 'soft' Brexit mean? Available at:

http://www.bbc.com/news/business-37500140

Boffey, D. (2017). Brexit divorce bill: what is it and how does it affect talks? Available at: https://www.theguardian.com/politics/2017/jun/20/brexit-divorce-bill-what-is-itand-how-does-it-affect-talks

Brexit. (2017). Available at: http://www.investopedia.com/terms/b/brexit.asp

Brexit war of words heats up as 'enemy' EU tells Britain to pay up. (2017). Available at: https://www.theguardian.com/politics/2017/oct/13/brexit-war-of-words-heats-upas-enemy-eu-tells-britain-to-pay-up

Brexit wins! Next stop: Frexit, Italexit and Swexit. (2016). Available at: http://www.washingtonsblog.com/2016/06/brexit-wins.html 
Brugman, B. (2017). Brexit: dirty, spicy or hairy? Why metaphor matter. Available at: https://socializingsciencevu.com/2017/06/02/brexit-dirty-spicy-or-hairy-whymetaphors-matter/

Carroll, N. (1994). Visual metaphor. In Aspects of metaphor. Hintikka, J. (ed.). Dordrecht: Kluwer, p. 189-218.

Castaño, C.M.D. (2013). Defining and characterizing the concept of Internet meme. In Revista CES psicología, 6 (2), p. 82-104.

Connolly, P. (2017). Bad Brexit metaphors. Available at:

http://www.huffingtonpost.co.uk/paul-connolly/brexit-metaphors_b_13995782.html

Davydyuk, Yu. \& Panasenko, N. (2016). Figuring the male and female: fire and water in Bradbury's (science) fiction. In Lege artis. Language yesterday, today, tomorrow. The journal of University of SS Cyril and Methodius in Trnava. Warsaw: De Gruyter Open, I (1), June 2016, p. 4-74. Available at: http://lartis.sk/wp-content/uploads/2017/01/ Davydyuk PanasenkoUCM.pdf

Devhumour. (2016). Available at:

https://twitter.com/dev_humor/status/776850657496236032

van Dijk, T.A. (2008b). Discourse and context: A sociocognitive approach. Cambridge: Cambridge University Press.

van Dijk, T.A. (2008a). Discourse and power. New York: Palgrave Macmillan.

Durden, T. (2016). Why the Brits really voted "Leave" (In 3 simple cartoons). Available at: $\quad$ http://www.zerohedge.com/news/2016-06-26/why-brits-really-voted-leave-3simple-cartoons.

EU divorce bill. (s.a.). Available at: https://en.wikipedia.org/wiki/EU_divorce bill Fauconnier, G. \& Turner, M. (2002). The way we think: Conceptual blending and the mind's hidden complexities. New York: Basic Books.

Fillmore, Ch.J. (1982). Frame semantics. In Linguistics in the morning calm: (Selected papers from the SICOL 1981). The Linguistic society of Korea (ed.). Seoul: Hanshin, p. 111-138. 
Forceville, C. (2009). Non-verbal and multimodal metaphor in a cognitive framework: agendas for research. In Multimodal metaphor. Forceville, Ch. \& Urios-Aparisi, E. (eds.). Berlin-New York: Mouton de Gruyter, p. 19-42.

Forceville, C. (1994). Pictorial metaphor in advertisements. In Metaphor and symbolic activity, 9, p. 1-29.

Forceville, C. (1996). Pictorial metaphor in advertising. London: Routledge.

Gibbs R., Jr. (2011). Evaluating conceptual metaphor theory. In Discourse processes, 48 , p. $529-562$.

Grady, J. (1999). A typology of motivation for conceptual metaphor: correlation vs. resemblance. In Metaphor in cognitive linguistics. Gibbs, R., Jr. \& Steen G. (eds.), Amsterdam. The Netherlands: John Benjamins, p. 79-100.

Gutteridge, N. (2017). Swexit is COMING. Available at: http://www.express.co.uk/news/politics/786371/European-Union-Sweden-follow-

Britain-out-EU-MEP-Peter-Lundgren\%0A\#brexit

Hanhimäki, J. (2016). What can history teach us about Brexit? Available at: http://graduateinstitute.ch/home/relations-publiques/news-at-the-institute/newsarchives.html/_news/corporate/2016/what-can-history-teach-us-about Hunt, A. \& Wheeler, B. (2017). Brexit: All you need to know about Brexit. Available at: http://www.bbc.com/news/uk-politics-32810887

Johnson, M. (1987). The body in the mind. Chicago: The University of Chicago Press. Johnson-Laird, P.N. (1983). Mental models. Cambridge: Cambridge University Press. Kövecses, Z. (2017). Levels of metaphor. In Cognitive linguistics, 28 (2), p. 209-370. Kövecses, Z. (2002). Metaphor: A practical introduction. Oxford: Oxford University Press.

Lakoff, G. (1987). Women, fire and dangerous things: What categories reveal about the mind. Chicago-London: The University of Chicago Press.

Lakoff, G. \& Johnson, M. (1980). Metaphors we live by. Chicago-London: The University of Chicago Press.

Lakoff, G. \& Johnson, M. (1999). Philosophy in the flesh: The embodied mind and its challenge to Eastern thought. New York: Basic Books. 
Lakoff, G. \& Turner, M. (1989). More than cool reason: A field guide to poetic metaphor. Chicago: The University of Chicago Press.

Landale, J. (2017). Brexit means what? Time for the metaphors to stop. Available at: http://www.bbc.com/news/uk-politics-40726215

Langacker, R.W. (1987). Foundations of cognitive grammar. Vol. I: Theoretical Prerequisites. Stanford: Stanford University Press.

Lecheler, S. (2014). Book review: Memes in digital culture by Limor Shifman. Available at: http://blogs.1se.ac.uk/lsereviewofbooks/2014/01/18/book-reviewmemes-in-digital-culture-by-limor-shifman/

Lemke, J.L. (2002). Travels in hypermodality. In Visual communication, 1 (3), p. 299325 .

McLuhan, M. (1994). Understanding media: the extension of man. Cambridge: MIT Press.

McNeill, D. (2005). Gesture and thought. Chicago: University of Chicago Press.

Metaphor and gesture. (2008). Cienki, A. \& Müller, C. (eds.). AmsterdamPhiladelphia: John Benjamins.

McNeill, D. (1992). Hand and mind: What gestures reveal about thought. Chicago: University of Chicago Press.

Mittelberg, I. \& Waugh, L.R. (2009). Metonymy first, metaphor second: A cognitivesemiotic approach to multimodal figures of speech in co-speech gesture. In Multimodal metaphor. Forceville, C. \& Urios-Aparisi, E. (eds.). Berlin-New York: Mouton de Gruyter, p. 329-356.

Morozova, O. (2017). Transparency across semiotic modes: An ecological stance. In Language - literature - the arts: A cognitive-semiotic interface. ChrzanowskaKluczewska, E. \& Vorobyova, O. (eds.). Frankfurt am Main: Peter Lang, p.49-68.

Musolff, A. (2017). Truths, lies, and figurative scenarios: metaphors at the heart of Brexit. In Journal of language and politics. Available at: http://www.jbeplatform.com/content/jmynals/10.1075/jlp.16033.mus

Nye, J.S., Jr. (2005). Soft power: the means to success in world politics. New York: Public Affairs. 
Oxford dictionaries word of the year 2016. Available at:

https://en.oxforddictionaries.com/word-of-the-year/word-of-the-year-2016

Oxford English dictionary. Available at: http://www.oed.com/

Ruiz de Mendoza, F.J. \& Galera Masegosa, A. (2014). Cognitive modeling. A linguistic perspective. Amsterdam-Philadelphia: John Benjamins.

Ruiz de Mendoza, F.J. \& Galera Masegosa, A. (2011). The contemporary theory of metaphor: Myths, developments and challenges. In Metaphor and symbol, 26, p.1-25. Sia partners (2016). BREXIT OR BREMAIN: A major difference for the powerhorse called European Union? Available at: http://en.finance.sia-partners.com/ 20160623/brexit-or-bremain-major-difference-powerhorse-called-european-union

Shifman, L. (2013). Memes in digital culture. Harvard, Mass.: The MIT Press.

Shutterstock. (2016). Available at: https://www.shutterstock.com/image-vector/noeuropean-union-red-stop-sign-733286335?src=NeoyA17Iq eLA GcbjTzMA-1-43

Starecat.com. (2016). Available at:

https://twitter.com/dev humor/status/776850657496236032

Tempest, M. (2017). Oxford English dictionary: the man who coined 'Brexit' first appeared on EURACTIVE blog. Available at: http://www.euractiv.com/section/ukeurope/news/oxford-english-dictionary-the-man-who-coined-brexit/

The Guardian. (2016-2017). Available at: https://www.theguardian.com/international The funniest EU memes. (2016). Available at: https://www.express.co.uk/ pictures/pics/6216/Funniest-EU-memes-hilarious-Brexit-pictures

Thrower, M. (2017). Brexit is not a poker game: How political metaphors mislead us. Available at: http://www.politics.co.uk/comment-analysis/2017/06/28/brexit-is-not-apoker-game-how-political-metaphors-mislead-u

Uberman, A. (2016). Death in metaphorical language. In Lege artis: Language yesterday, today, tomorrow. The journal of University of SS Cyril and Methodius in Trnava. Warsaw: De Gruyter Open, I (2), December 2016, p. 171-211. Available at: http://lartis.sk/wp-content/uploads/2017/02/Uberman.pdf

UK flag separating from European Union flag. (2017). Available at: https://www. freepik.com/free-vector/uk-flag-seperating-from-european-union-flag 893480.htm 
Usherwood, S. (2017). Three unhelpful metaphors for understanding Brexit. Available at: $\quad$ https://blogs.surrey.ac.uk/politics/2017/04/28/three-unhelpful-metaphors-forunderstanding-brexit/

United Kingdom withdrawal from the European Union / Brexit. Available at: http://knowymymeme.com/memes/events/united-kingdom-withdrawal-from-theeuropean-union-brexit

Whitman, R.G. (2016). Brexit or Bremain: what future for the UK's European diplomatic strategy? In International affairs, 92 (3), p. 509-529.

Zbikowski, L. (2009). Music, language, and multimodal metaphor. In Multimodal metaphor. Forceville, C., Urio-Apparisi, E. (eds.). Berlin-New York: Mouton de Gruyter, p. 359-381.

Zhabotynska, S.A. (2010). Principles of building conceptual models for thesaurus dictionaries. In Когніція, комунікація, дискурс, 1, p. 75-92.

Zheltukhina, M.R., Krasavsky, N.A., Ponomarenko, E.B., Aleshchanova, I.V. \& Pavlov, P.V. (2016). Political Facebook posts using ideological symbols for media image designing of Russia as enemy. In International journal of environmental and science education, 11 (18), p. 12005-12013.

\begin{tabular}{|c|c|}
\hline \begin{tabular}{l}
\multicolumn{1}{c}{ Contact data } \\
Olena Morozova \\
DSc. (Philology), \\
Professor, Department of \\
English Philology, \\
V.N. Karazin Kharkiv \\
National University, 4, \\
Svobody Sq., Kharkiv 61022, \\
Ukraine e-mail: \\
elena.i.morozova@gmail.com
\end{tabular} & $\begin{array}{l}\text { Cognitive linguistics, } \\
\text { discourse studies, } \\
\text { multimodal and } \\
\text { ecological approaches } \\
\text { to language }\end{array}$ \\
\hline
\end{tabular}

\section{Résumé in English}

This article offers a linguistic analysis of the conceptual metaphors of Brexit, in which the source and the target belong to the same or different semiotic modes. The sample, 
selected from the hypertextual communicative space of the Internet, includes 200 conceptual metaphors with the referent BREXIT that have a mono-, multi-, or hypermodal manifestation in the verbal and / or visual (static) mode/s. The research adapts the three-level typology of the cognitive models developed by Ruiz de Mendoza and Galera Masegosa to accommodate multimodal characteristics of the metaphors under consideration. It is shown that metaphoric representations of the United Kingdom's withdrawal from the European Union may be underpinned by different high-level cognitive models; this variation reflects the author's stance towards the event. The phases of Brexit are associated with different image-schematic cognitive models, and this impinges on the range of image-based metaphors of Brexit, which involve low-level cognitive models. The monomodal verbal (the written mode) metaphors of Brexit tend to be used strategically in order to impose a particular ideological position upon the addressee. Combining the affordances of multimodality and hypermodality enables the producer of the metaphor to enter into a dialogue with Internet users, thus resisting the monologism of traditional media genres, providing the addressee with an access to discourse diversity, and multiplying the potential of conceptual metaphors deployed in different modes.

Keywords: Brexit, cognitive model, conceptual metaphor, Internet, monomodality, multimodality.

\section{Résumé in German}

Dieser Artikel präsentiert eine linguistische Analyse von konzeptuellen Metaphern, die sich auf den Brexit beziehen, in denen die Ursprungs- und Zieldomäne zum gleichen oder unterschiedlichen semiotischen Modus gehören. Das Samplewurde aus dem hypertextuellen kommunikativen Raum des Internets extrahiertund enthält 200 konzeptuelle Metaphern mit dem Referent BREXIT, die eine mono-, multi- oder hypermodale Repräsentation im verbalen und / oder visuellen (statischen) Modus haben. In dieser Forschung wurde die dreistufige Typologie der kognitiven Modelle, die von Ruiz de Mendoza und Galera Masegosa entwickelt wurde, der multimodalen 
Eigenschaften der behandelnden Metaphern angepasst. Es wurde gezeigt, dass verschiedene abstrakte kognitive Modelle der Bedeutung der metaphorischen Darstellungen des Austritts des Vereinigten Königreichs aus der Europäischen Union zugrunde liegen können; die Auffassung des Autors in Bezug auf dieses Ereignis bedingt ihre Variabilität. Die Phasen des Brexits werdem mit verschiedenen imageschematischen Modellen verbunden, und die wiederum bestimmen die Image-Schemas auf niedrigerem Niveau. Es ergibt sich eine Tendenz, monomodale verbale (im schriftlichen Modus) Metaphern des Brexits strategisch zu verwenden, um so dem Adressaten einen bestimmten ideologischen Standpunkt aufzuzwingen. Die Verbindung von den Möglichkeiten der Multimodalität und Hypermodalität gibt dem Produzenten der Metapher die Möglichkeit, in einen Dialog mit Benutzern des Internets zu treten, und dadurch überwindet man den Monologismus der traditionellen Medien, ermöglicht dem Adressaten den Zugang zur diskursiven Vielfalt und steigert das Potential der konzeptuellen Metaphern, die in den verschiedenen Modi angewendet werden.

Stichwörter: Brexit, kognitives Modell, konzeptuelle Metapher, Internet, Monomodalität, Multimodalität.

\section{Résumé in French}

Cet article propose une description linguistique des métaphores conceptuelles du Brexit, dont le référent et le corrélat appartiennent au même mode sémiotique ou aux différents. L'ensemble des matériaux étudiés, sélectionnés de l'espace communicatif hypertextuel d'Internet, comprend 200 métaphores conceptuelles avec le référent BREXIT qui ont la représentation mono-, multi- ou hyper-modal dans le mode verbal et / ou visuel (statique)/s. La recherche adapte la typologie à trois niveaux des modèles cognitifs développés par Ruiz de Mendoza et Galera Masegosa pour tenir compte des caractéristiques multimodales des métaphores considérées. Il est démontré que les représentations métaphoriques du retrait du Royaume-Uni de l'Union Européenne peuvent être soutenues par les différents modèles cognitifs de haut niveau; cette 
variation reflète la position de l'auteur à l'égard de l'événement. Les phases du Brexit sont associées aux différents modèles cognitifs image- schématiques, qui affecte la variation des métaphores images du Brexit, qui impliquent des modèles cognitifs de bas niveau. Les métaphores verbales monomodales (le mode écrit) du Brexit tendent à être utilisées stratégiquement pour imposer une position idéologique particulière au destinataire. La combinaison des affordances de la multimodalité et de l'hypermodalité permet au producteur de la métaphore d'entrer en dialogue avec les internautes, surmontant ainsi le monologue des genres médiatiques traditionnels, donnant au destinataire accès à la diversité discursive et construisant le potentiel des métaphores conceptuelles incarnées par les modes différents.

Mots-clés: Brexit, Internet, métaphore conceptuelle, modèle cognitif, monomodalité, multimodalité.

\section{Résumé in Russian}

В данной статье предлагается лингвистическое описание концептуальных метафор Брекзита, в которых референт и коррелят принадлежат к одному и тому же семиотическому модусу или к разным. Массив исследованного материала, извлеченный из гипертекстового коммуникативного пространства Интернет, включает 200 концептуальных метафор с референтом БРЕКЗИТ, которые получили моно-, мульти- или гипермодальное воплощение в вербальном и / или визуальном (статическом) модусе/ах. В данном исследовании трехуровневая типология когнитивных моделей, которую разработали Руис-де-Мендоса и Галера Масегоса, адаптирована к рассмотрению мультимодальных характеристик рассматриваемых метафор. Продемонстрировано, что в основе значения метафорических репрезентаций выхода Соединенного Королевства из Евросоюза могут лежать различные когнитивные модели высокого уровня; их вариативность обусловлена позицией автора по отношению к данному событию. Фазы Брекзита ассоциируются с разными когнитивными образ-схемными моделями, что определяет вариативность образных метафор Брекзита, в которых 
задействованы когнитивные модели низкого уровня. Наблюдается тенденция к использованию мономодальных вербальных (в письменном модусе) метафор Брекзита в стратегических целях для того, чтобы навязать адресату определенную идеологическую позицию. Сочетание аффордансов мультимодальности и гипермодальности дает создателю метафоры возможность вступить в диалог с пользователями Интернета, таким образом преодолевая монологизм традиционных медиа жанров, обеспечивая адресату доступ к дискурсивному многообразию и увеличивая потенциал концептуальных метафор, получающих свое воплощение в различных модусах.

Ключевые слова: Брекзит, когнитивная модель, концептуальная метафора, Интернет, мономодальность, мультимодальность.

Article was received by the editorial board 07.11.17.

Reviewed 09.11.17. and 10.11.17.

Similarity Index 10\% 